\title{
Organic Manures and Crop Residues as Fertilizer Substitutes: Impact on Nitrous Oxide Emission, Plant Growth and Grain Yield in Pre-Monsoon Rice Cropping System
}

\author{
Anushree Baruah, Kushal Kumar Baruah* \\ Department of Environmental Science, Tezpur Central University, Tezpur, India \\ Email: ${ }^{*}$ kushalbaruah@tezu.ernet.in
}

Received 1 June 2015; accepted 25 July 2015; published 29 July 2015

Copyright (C) 2015 by authors and Scientific Research Publishing Inc. This work is licensed under the Creative Commons Attribution International License (CC BY). http://creativecommons.org/licenses/by/4.0/

(c) () D Open Access

\section{Abstract}

It has been previously argued that application of organic residues added in soils has a great impact on soil quality, grain productivity as well as greenhouse gas emissions. Substitution of chemical fertilizers has become a common practice in agricultural systems which consequently affect the greenhouse gas emissions from agricultural fields. To observe the effects of organic manures and crop residues amendments, five fertilizer treatments including conventional inorganic nitrogen fertilizer-NPK, cow manure, rice straw, poultry manure and sugarcane bagasse were applied in the field for two consecutive pre-monsoon rice seasons. Addition of rice straw, poultry manure and sugarcane bagasse decreased the cumulative $\mathrm{N}_{2} \mathrm{O}$ emissions by $14 \%$ and $31 \%$, and by $1 \%$ and $7 \%$ and $5 \%$ and $3 \%$ in 2012 and 2013 respectively when compared with conventional fertilizer treatment (NPK) in both the seasons. Yield differences were not significant $(p>0.005)$ amongst the treatments, however, a slight increase was observed due to rice straw amendment over control. Soil organic carbon decreased by $11 \%-17 \%$ under the application of organic residues which might have contributed to lower $\mathrm{N}_{2} \mathrm{O}$ emissions from the plots. Results of carbon equivalent emission (CEE) and carbon efficiency ratio (CER) indicated that incorporation of rice straw during premonsoon rice season had the potential to reduce the $\mathrm{N}_{2} \mathrm{O}$ emissions and yield scaled emissions of rice production at lower level than the conventional farmers' practice of using chemical fertilizers (NPK).

\section{Keywords}

Organic Residues, Nitrous Oxide $\left(\mathrm{N}_{2} \mathrm{O}\right)$ Emission, Rice, Yield, Residue Effect Intensity (REI)

\footnotetext{
${ }^{*}$ Corresponding author.
}

How to cite this paper: Baruah, A. and Baruah, K.K. (2015) Organic Manures and Crop Residues as Fertilizer Substitutes: Impact on Nitrous Oxide Emission, Plant Growth and Grain Yield in Pre-Monsoon Rice Cropping System. Journal of Environmental Protection, 6, 755-770. http://dx.doi.org/10.4236/jep.2015.67069 


\section{Introduction}

Agricultural lands are considered as one of the major anthropogenic sources of $\mathrm{N}_{2} \mathrm{O}$ emissions which are produced in the soils by biological nitrification and denitrification and are estimated to account for more than $60 \%$ of the calculated annual atmospheric $\mathrm{N}_{2} \mathrm{O}$ emission [1]. In the last few decades, $\mathrm{N}_{2} \mathrm{O}$ emissions have become more variable and have increased exponentially with the use of Nitrogen $(\mathrm{N})$ fertilization [2] [3], which has resulted in about $17 \%$ increase in agricultural $\mathrm{N}_{2} \mathrm{O}$ emissions [4]. Fertilization is one of the key factors influencing the production and consumption of $\mathrm{N}_{2} \mathrm{O}$ [5] since $\mathrm{N}$ is applied through fertilizers, manures and other $\mathrm{N}$ sources are not used efficiently by the crops [6], the excess $\mathrm{N}$ is susceptible to loss as $\mathrm{N}_{2} \mathrm{O}$ emissions [7]. Soil management systems that add organic wastes and incorporate carbon have been evaluated as important alternatives for increasing the capacity of atmospheric carbon sinks and mitigation of global warming [8]. The application of mineral fertilizers and organic residues can alter soil greenhouse gas (GHG) emissions and this intensity of emissions varies with the functions of several factors such as changes in temperature, precipitation and waste composition [9]. Among the agricultural crops, rice paddies have received increased global concerns for their contribution to greenhouse gas emissions. Recent studies have suggested that the increasing use of mineral nitrogen $(\mathrm{N})$ in rice paddies can also contribute significantly to $\mathrm{N}_{2} \mathrm{O}$ emissions [10] [11]. The use of chemical fertilizers with organic manure has been widely recommended for sustaining agricultural production in Asia and Africa, with their degraded soil fertility and soil quality [12]. In India, the farmers combine the use of both chemical $\mathrm{N}$ fertilizer and organic manures to improve soil health and nutrient uptake by plants and get better yield [13]. Organic amendment, besides its nutrient values, can affect soil organic C pool [14], soil nutrients and microbial activities [12] which are some of the controlling factors in the emissions of $\mathrm{N}_{2} \mathrm{O}$ to the atmosphere.

There are contradictory reports of organic amendments influencing $\mathrm{N}_{2} \mathrm{O}$ emissions [15] [16] and increasing its release from the soils. The magnitude of $\mathrm{N}_{2} \mathrm{O}$ emissions depends on the type, quality or chemical composition of the residues added in the soil [17] as organic fertilizers. However, if a balanced amount of manures and fertilizer are incorporated to manage the Carbon (C) and Nitrogen (N) sinks in soil then the question of increased $\mathrm{N}_{2} \mathrm{O}$ emissions can be addressed and proved to be a practical and effective way to improve soil quality, enhance yield and mitigate GHG emissions [18].

To meet the food demands of the growing population, cultivation of rice and wheat will be intensified. Therefore, it is important to establish technologies and practices for reducing $\mathrm{N}_{2} \mathrm{O}$ emissions from rice paddy fields while sustaining or increasing rice production [19]. The main livelihood of the people of north-eastern (NE) part of India is predominantly agriculture dependent and residue return is widely adopted by farmers to improve soil properties, maintain soil fertility and enhance crop productivity. In NE India, impacts of $\mathrm{N}$ fertilization and application of organic residues on crop yield and $\mathrm{N}_{2} \mathrm{O}$ emissions from this region of India are not well documented. The present study focuses on how incorporation of organic residues in substitution of chemical $\mathrm{N}$ fertilizers could affect the crop productivity, magnitude of $\mathrm{N}_{2} \mathrm{O}$ emissions, and soil carbon storage in a premonsoon rice ecosystem in a part of NE India. Field experiments were conducted for two consecutive seasons in 2012 and 2013 from April to July to 1) observe the effects of organic residues application on plant growth and rice productivity, 2) measure the impact of residue application on nitrous oxide emission and 3) work out the potential option of mitigating $\mathrm{N}_{2} \mathrm{O}$ emissions without sacrificing yield and soil biological quality.

\section{Experimental Methods}

\subsection{Study Area}

Field experiments were conducted during two consecutive seasons in 2012 and 2013 at Tezpur (Central) University campus, Napaam, Sonitpur District $\left(26^{\circ} 41^{\prime} \mathrm{N}, 9^{\circ} 50^{\prime} \mathrm{E}\right)$ along the Brahmaputra valley (North Bank Plain Zone) of Assam, India. The region is subtropical humid and is characterized by hot-wet summers. Daily air temperature and precipitation were recorded from April to July for both the years of experimentation from a weather station located in the University campus. Total rainfall received was $1099.8 \mathrm{~mm}$ in 2012 and 1062.7 $\mathrm{mm}$ in 2013 during the crop growth period (Figure 1). The soil of the experimental area is characterized by recent and old alluvium riverine soils with sandy-loam to silt loam texture (USDA classification). Soil samples were collected from five different points of the experimental plot prior to the application of fertilizers and residues and analyzed for initial physical and chemical properties (Table 1). 


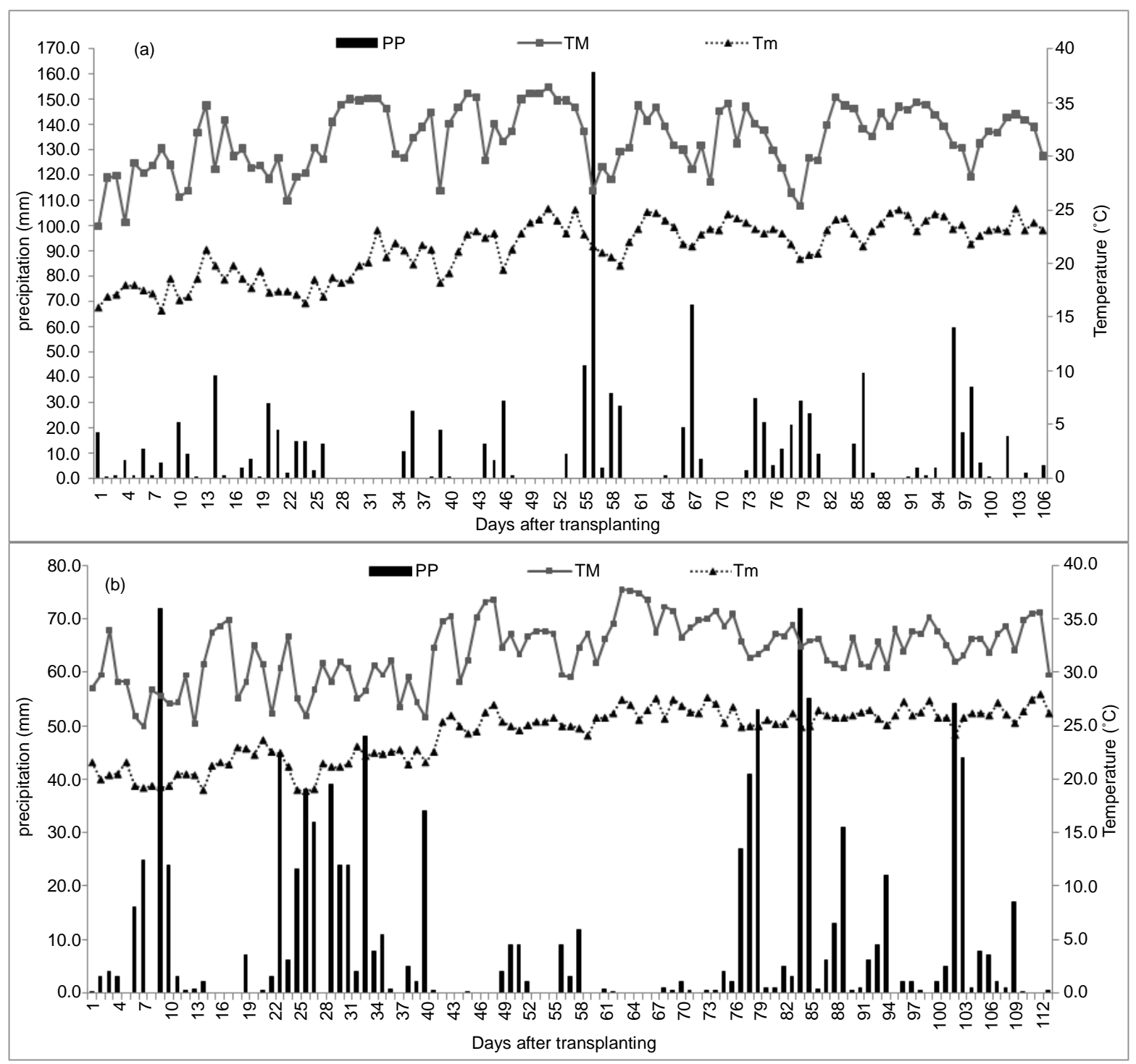

Figure 1. Distribution of precipitation and maximum and minimum temperatures during the experimental period for (a) 2012 and (b) 2013.

Table 1. Basic soil properties of the experimental field at 0 - $10 \mathrm{~cm}$ depth (mean \pm standard deviation).

\begin{tabular}{cc}
\hline Property & $60.79 \pm 0.61$ \\
Sand (\%) & $20.25 \pm 0.83$ \\
Silt (\%) & $19.29 \pm 0.96$ \\
Clay (\%) & $5.69 \pm 0.17$ \\
$\mathrm{pH}$ & $1.21 \pm 0.10$ \\
Bulk density $\left(\mathrm{gm} \cdot \mathrm{cc}^{-1}\right)$ & $12.33 \pm 0.96$ \\
Cation Exchange Capacity (meq $\left.100 \mathrm{~g} \mathrm{~g}^{-1}\right)$ & $0.59 \pm 0.03$ \\
Electrical conductivity $\left(\mathrm{mmhos} 100 \mathrm{~g}^{-1}\right)$ & $61.47 \pm 2.64$ \\
Soil moisture content (\%) & $0.98 \pm 0.07$ \\
Soil organic carbon (\%) & $16.67 \pm 2.70$ \\
Total Carbon $\left(\mathrm{mg} \cdot \mathrm{g}^{-1}\right)$ & $114.76 \pm 6.99$ \\
Available nitrogen $\left(\mathrm{kg} \cdot \mathrm{ha}^{-1}\right)$ & $32.89 \pm 4.51$ \\
Available phosphorus $\left(\mathrm{kg} \cdot \mathrm{ha}{ }^{-1}\right)$ & $175.85 \pm 12.90$ \\
Available potassium $\left(\mathrm{kg} \cdot \mathrm{ha}^{-1}\right)$ & \\
\hline
\end{tabular}




\subsection{Experimental Design and Field Management}

Experimental area was prepared by thoroughly ploughing and puddling 4 to 5 times followed by harrowing and laddering 20 days before transplanting. 25 days old seedlings of a popular high yielding pre-monsoon rice variety Lachit (Parent $=$ CRM13-3241/Kalinga II; duration of the variety $=115-120$ days) were transplanted in a well prepared field on $9^{\text {th }}$ April 2012 and $10^{\text {th }}$ April 2013, at a row to row spacing of $20 * 15 \mathrm{~cm}$ in each plot of $16 \mathrm{~m}^{2}=4 \mathrm{~m} \times 4 \mathrm{~m}$. Five treatments with conventional fertilizer (NPK), and organic residues viz., Cow manure $\left(\mathrm{CN}^{1}=25: 1\right)$, Rice straw $(\mathrm{CN}=41: 1)$, Poultry manure $(\mathrm{CN}=15: 1)$ and Sugarcane bagasse $(\mathrm{CN}=108: 1)$ were incorporated in the field prior to transplanting for uniform mixing. Each treatment was replicated into 5 subplots and laid in a randomized block design (RBD). Treatments selected were applied following the recommendations by the Department of Agriculture, Government of Assam, India. The recommended dose of inorganic fertilizer i.e., NPK, was applied in the form of Urea $(\mathrm{N})$, Super Phosphate $\left(\mathrm{P}_{2} \mathrm{O}_{5}\right)$ and Muriate of Potash $\left(\mathrm{K}_{2} \mathrm{O}\right)$ at the rate of 40:20:20 kg.ha ${ }^{-1}$ and was taken as control (T1). The half quantity of $\mathrm{N}$ (urea) and whole quantity of $\mathrm{P}_{2} \mathrm{O}_{5}$ and $\mathrm{K}_{2} \mathrm{O}$ was applied at the time of final puddling. Remaining part of urea was split in two equal halves and one part was applied at the tillering stage (30 DAT ${ }^{2}$ ) and other half at panicle initiation stage (56 DAT). The other treatments selected with different $\mathrm{C}$ and $\mathrm{N}$ content viz., cow manure (T2), rice straw (T3), poultry manure (T4) and sugarcane bagasse (T5) were applied @ 10 ton $\cdot \mathrm{ha}^{-1}$ on dry weight basis (without any inorganic fertilizer) at the time of final puddling (Table 2). All management practices, such as irrigation, application of manures and fertilizers, plant protection measures, etc., were followed as recommended by the Department of Agriculture, Government of Assam, India. The crop is rain dependent (rainfed) and hence no irrigation was applied after establishment of the crop. However one irrigation for land soaking was applied before preparatory tillage and another irrigation of depth $=5-7 \mathrm{~cm}$ was applied before final puddling. At maturity crop was harvested manually and post harvest data were recorded. Other management practices such as weeding, cleaning and crop protection were uniformly maintained during the experimental periods. At maturity crop was harvested manually and post harvest data were recorded.

\subsection{Gas Sampling and Nitrous Oxide Estimation}

Gas samples were collected from the day of transplanting (0 Days after transplanting, DAT) onwards at 7 day interval, 2 times a day throughout the growth period. The closed chamber technique [20]-[22] was used to collect $\mathrm{N}_{2} \mathrm{O}$ gas from the soil - plant system. The chambers used for gas collection were made of $6 \mathrm{~mm}$ thick acrylic sheets of $50 \mathrm{~cm} \times 30 \mathrm{~cm} \times 70 \mathrm{~cm}$ (length $\times$ breadth $\times$ height) and equipped with a circulating fan to homogenize the air inside the chamber. The chambers were covered with aluminum foil to minimize the affect of temperature on the flux inside the chambers. To match with the crop growth, chamber with $100 \mathrm{~cm}$ height was used from panicle initiation stage onward. A rectangular shaped aluminum channel $(50 \mathrm{~cm} \times 30 \mathrm{~cm})$ was inserted in the soil after transplanting to accommodate the chamber. Gas samples were drawn from the chambers using a 50 $\mathrm{ml}$ airtight syringe fitted with a three-way stop-cock through a self-sealing rubber septum. The samples were drawn at fixed interval of $0,15,30$ and 45 minutes respectively starting at 0900 hrs in the morning and again at 1400 hrs in the evening from 0 DAT onwards at weekly interval. Nitrous oxide $\left(\mathrm{N}_{2} \mathrm{O}\right)$ concentration in the gas samples were analyzed using a gas chromatograph (Varian, 3800 GC) equipped with a ${ }^{63} \mathrm{Ni}$ electron capture detector (ECD) within 4 - 6 hours of collection. The gas chromatograph was calibrated by standard $\mathrm{N}_{2} \mathrm{O}$ obtained

Table 2. Properties of the organic residues applied during both years of experimentation.

\begin{tabular}{|c|c|c|c|c|c|}
\hline Treatment & Fertilizer/Organic residue & Total C (mg $\left.\cdot \mathrm{g}^{-1}\right)$ & Total N (mg·g $\left.{ }^{-1}\right)$ & $\mathrm{C}: \mathrm{N}$ & N applied@10 thha ${ }^{-1}$ \\
\hline $\mathrm{T} 1$ & NPK (control) & - & 4.0 & -- & $40 \mathrm{~kg} \cdot \mathrm{N} \cdot \mathrm{ha}^{-1}$ \\
\hline $\mathrm{T} 2$ & Cow manure (CD) & 300.0 & 12.0 & 25 & $120 \mathrm{~kg} \cdot \mathrm{N} \cdot \mathrm{ha}^{-1}$ \\
\hline T3 & Rice straw (RS) & 446.9 & 10.9 & 41 & $109 \mathrm{~kg} \cdot \mathrm{N} \cdot \mathrm{ha}^{-1}$ \\
\hline $\mathrm{T} 4$ & Poultry manure (PM) & 135.0 & 9.0 & 15 & $90 \mathrm{~kg} \cdot \mathrm{N} \cdot \mathrm{ha}^{-1}$ \\
\hline T5 & Sugarcane bagasse (SCB) & 410.9 & 3.8 & 108 & $38.04 \mathrm{~kg} \cdot \mathrm{N} \cdot \mathrm{ha}^{-1}$ \\
\hline
\end{tabular}

${ }^{1} \mathrm{CN}$-Carbon-nitrogen ratio.

${ }^{2}$ DAT_-Days after transplanting. 
from CSIR-National Physical Laboratory, New Delhi, India. The injector, column and detector temperature were maintained at $80^{\circ} \mathrm{C}, 150^{\circ} \mathrm{C}$ and $300^{\circ} \mathrm{C}$ respectively. Nitrogen $\left(\mathrm{N}_{2}\right)$ was used as a carrier gas with a flow rate of $15 \mathrm{ml} \cdot \mathrm{min}^{-1}$. $\mathrm{N}_{2} \mathrm{O}$ fluxes were estimated by successive linear increase of gas concentration inside the box at each sampling time $(0,15,30,45 \mathrm{~min})$. The average of morning and evening fluxes were considered as the flux value for the day and calculated according to the equation of Wang et al. (2011) [21].

\subsection{Seasonal Integrated Flux ( $\left.E_{\text {sif }}\right)$}

Cumulative $\mathrm{N}_{2} \mathrm{O}$ emission is expressed as seasonal integrated flux $\left(E_{\text {sif }}\right)$ in mg $\mathrm{N}_{2} \mathrm{O}-\mathrm{N} \mathrm{m}^{-2}$ for the entire crop growth period was computed by the method given by [22] by using the following formula:

$$
\text { Cumulative } \mathrm{N}_{2} \mathrm{O} \text { emission }\left(E_{\text {sif }}\right)=\sum_{i=1}^{n}(R i \times D i)
$$

where $R i$ is the mean gas emission, $D i$ is the number of days in the sampling interval and $n$ is the number of sampling times.

\subsection{Auxiliary Field Measurements}

Prior to rice cultivation soil samples were collected randomly from different locations of the experimental plot up to a depth of $0-10 \mathrm{~cm}$ with the help of a soil core $(5 \mathrm{~cm}$ diameter, $30 \mathrm{~cm}$ height) and mixed thoroughly to prepare a single composite sample which was analyzed for physical and chemical parameters (Table 1). Soil texture was determined by the International Pipette Method. Bulk density, Soil moisture, available (mineralized) soil nitrogen $(\mathrm{N})$, phosphorus $(\mathrm{P})$ and potassium $(\mathrm{K})$ content were determined following Page et al. [23]. Total soil organic carbon, total carbon, soil nitrate- $\mathrm{N}$ and soil ammonium- $\mathrm{N}$ were analyzed at weekly interval at all the sampling days. The samples were collected with a core sampler $(5 \mathrm{~cm}$ diameter) inserted in the soil $(0-10 \mathrm{~cm})$ from 5 sections in each replicate of every treatment and mixed together to make one composite sample. Air dried soil samples were passed through $2 \mathrm{~mm}$ mesh sieve and analyzed for other parameters. The estimation of soil nitrate- $\mathrm{N}$ was done by colorimetric method after reaction with phenol disulphonic acid [24] and ammonium- $\mathrm{N}$ by extracting the soils with ultra pure water after sonicating the samples for 90 minutes in $70^{\circ} \mathrm{C}$ through a milipore filter in ion chromatography (Compact IC 882 plus, make Metrohm, Germany). Total carbon content was estimated in CHN analyzer (TrueSpec CHN macro determinator, LECO corporation USA), total organic carbon (SOC) by the dry combustion method at $1000^{\circ} \mathrm{C}$ analyzed using TOC analyzer (Multi N/C 2100S with HT 1300 module, Analytik Zena, Germany) [25]. Soil temperature was measured with a soil thermometer on every sampling date. Soil water content (\%) was measured by gravimetric method [23]. Soil pH was measured in 1:2.5 ratio (soil: water) with a $\mathrm{pH}$ meter immediately after sample collection.

\subsection{Estimation of Plant, Yield and Yield Attributing Parameters}

During the crop growth period, destructive sampling was done to estimate above ground and below ground biomass during vegetative, reproductive and maturation stages. The roots were separated from the shoot portion carefully and washed thoroughly to remove any soil particles under running water over a sieve. Biomass was recorded by drying the samples in an oven at $75^{\circ} \mathrm{C} \pm 2^{\circ} \mathrm{C}$ till a constant weight was obtained and weighed. The grains were separated from the straw, dried and weighed for yield. Yield attributing parameters (sterility \%, fertile panicle per square meter, harvest index, etc) were recorded after harvesting by standard methods. The Harvest index (HI) was calculated after Yasin [26] as in Equation (2):

$$
\mathrm{HI}=\frac{\text { economical yield }}{\text { biological yield }} \times 100
$$

\subsection{Carbon Equivalent Emissions, Carbon Efficiency Ratio and Carbon Storage}

The carbon equivalent emissions (CEE) $\left(\mathrm{kg} \mathrm{CO}_{2} \mathrm{eq} \mathrm{ha}^{-1}\right.$ ) were calculated as in Equation (3):

$$
\mathrm{CEE}=\mathrm{N}_{2} \mathrm{O} \text { emission } \times 298 \times 12 / 44
$$

The global warming potential of $\mathrm{N}_{2} \mathrm{O}$ was taken as 298 [27].

Carbon efficiency ratio (CER) of the treatments was calculated as given Equation (4): 


$$
\mathrm{CER}=\text { grain yield of the crop/CEE }
$$

Both CEE and CER were estimated according to Bhatia et al. [7].

In addition, as proposed by Zhang et al. [28] for highlighting the effect of residues over the other factors, we measured the residue effect intensity (REI, \%) which allows an analysis of any change in organic residue effect on soil and crop productivity as well as nitrous oxide emission during a crop growth period. REI was calculated by the following Equation (5):

$$
\operatorname{REI}(\%)=\left[\frac{Q_{\text {treated }}-Q_{\text {Control }}}{Q_{\text {Control }}}\right] \times 100
$$

where REI is the residue effect intensity in \% of a given parameter, $Q_{\text {treated }}$ and $Q_{\text {control }}$ is the soil quality, yield and yield attributing parameters or cumulative $\mathrm{N}_{2} \mathrm{O}$ emission $\left(E_{\text {sif }}\right)$ values under a certain treatment, respectively.

\subsection{Statistical Analysis and Calculations}

The SPSS 16.0 software package was used to calculate the Pearson correlation of various soil parameters, plant physiological parameters and yield parameters with $\mathrm{N}_{2} \mathrm{O}$ emission from the treatments. The datasets were subjected to analyze significant pooled difference between the treatments and least significant difference (LSD). One way Analysis of variance (ANOVA) was conducted to analyze the significance of difference of different parameters among the treatments and subsequently Duncan Multiple Range Test (DMRT) to find out the critical differences between the recorded parameters by the same statistical package.

\section{Results and Discussion}

\subsection{Effect of Organic Manures and Crop Residues on Nitrous Oxide $\left(\mathrm{N}_{2} \mathrm{O}\right)$ Emission}

The seasonal variations and dynamics of $\mathrm{N}_{2} \mathrm{O}-\mathrm{N}$ emission from the plots treated with different organic residues for 2012 and 2013 are presented in Figure 2. Data on seasonal amounts and overall magnitude of variation in emissions from the treatment plots are organized in Table 3.

Seasonal dynamics of nitrous oxide emission revealed a similar pattern between the two periods of crop growing season which was affected by daily precipitation (mm) and soil water content (\%) under different organic residues applied. Reduction in $\mathrm{N}_{2} \mathrm{O}$ emission from the plots treated with rice straw (RS, T3) over the control (NPK, T1) was clearly visible. The seasonal total of $\mathrm{N}_{2} \mathrm{O}-\mathrm{N}$ emission under T1, T2, T3, T4 and T5 were 2104.23, 2379.26, 1814.86, 2068.06 and $1998.16 \mathrm{~N}_{2} \mathrm{O}-\mathrm{N} \cdot \mu \mathrm{gm} \cdot \mathrm{m}^{-2} \cdot \mathrm{hr}^{-1}$ in 2012 and 2183.30, 2124.34, 1489.82, 2025.05, and $2115.13 \mathrm{~N}_{2} \mathrm{O}-\mathrm{N} \mu \mathrm{gm} \cdot \mathrm{m}^{-2} \cdot \mathrm{hr}^{-1}$ in 2013 respectively.

The seasonal cumulative emission $\left(E_{\text {sif }}\right)$ was highest in T2 $\left(399.7 \mathrm{~kg} \mathrm{~N}_{2} \mathrm{O}-\mathrm{N} \mathrm{ha}^{-1}\right)$, followed by $\mathrm{T} 1$ (3.53 kg $\mathrm{N}_{2} \mathrm{O}-\mathrm{N} \mathrm{ha}^{-1}$ ), T4 (3.47 $\left.\mathrm{kg} \mathrm{N}_{2} \mathrm{O}-\mathrm{N} \mathrm{ha}^{-1}\right)$, T5 (3.35 kg N $\mathrm{N}_{2} \mathrm{O}-\mathrm{N} \mathrm{ha}^{-1}$ ) and T3 $\left(3.05 \mathrm{~kg} \mathrm{~N}_{2} \mathrm{O}-\mathrm{N} \mathrm{ha}^{-1}\right)$ in 2012 and highest in T1 (3.66 $\mathrm{kg} \mathrm{N}_{2} \mathrm{O}-\mathrm{N} \mathrm{ha}^{-1}$ ), followed by T2 (3.57 $\mathrm{kg} \mathrm{N}_{2} \mathrm{O}-\mathrm{N} \mathrm{ha}^{-1}$ ), T5 (3.54 kg N2O-N ha $\left.{ }^{-1}\right)$, T4 (3.40 $\mathrm{kg} \mathrm{N}_{2} \mathrm{O}-\mathrm{N} \mathrm{ha}^{-1}$ ) and $\mathrm{T} 3\left(2.50 \mathrm{~kg} \mathrm{~N}_{2} \mathrm{O}-\mathrm{N} \mathrm{ha}^{-1}\right.$ ) in 2013 (Figure 3). The impact of treatments T2, T3 and T4 on seasonal total of $\mathrm{N}_{2} \mathrm{O}$ emission was different in the two years of experimentation with lower emissions in 2013 over 2012. As compared with the corresponding control (T1), the seasonal cumulative emission decreased by $14 \%$ and 31\%, and by $1 \%$ and 7\% and 5\% and 3\% in T3, T4 and T5 in 2012 and 2013 respectively. While T2 did not reveal consistent results in 2012 there was an increase in emission by $12 \%$ but a decrease by $2 \%$ during the second season. The seasonal cumulative emission revealed a significant variation $(\mathrm{p}<0.001)$ from each other during both the years.

The $\mathrm{N}_{2} \mathrm{O}$ emissions increased from the active tillering stage (28 DAT) up to panicle initiation (56 DAT) and to the maturation (84 DAT) of the crop after which there was a decline in emission irrespective of the treatments. In both the years of experimentation the emission at initial stage (0 - 21 DAT) was less compared to the later stages (28 - 98 DAT) of the crop growth in all the treatments. During the active vegetative stage soil is enriched with $\mathrm{C}$ by root exudates which act as a source of nutrients to the microbes responsible for $\mathrm{N}_{2} \mathrm{O}$ production resulting in high emission peaks of $\mathrm{N}_{2} \mathrm{O}$ during this period [29] [30]. During maturation of the crop, high emission peaks were observed which may be attributed to the decomposition of organic matter in the residues [31] and increased $\mathrm{N}$ mineralization [32] in the plots treated with organic residues. Decomposition of leaf litter and roots contribute to high substrate availability in the rice rhizosphere for $\mathrm{N}_{2} \mathrm{O}$ production resulting in increased $\mathrm{N}_{2} \mathrm{O}$ 


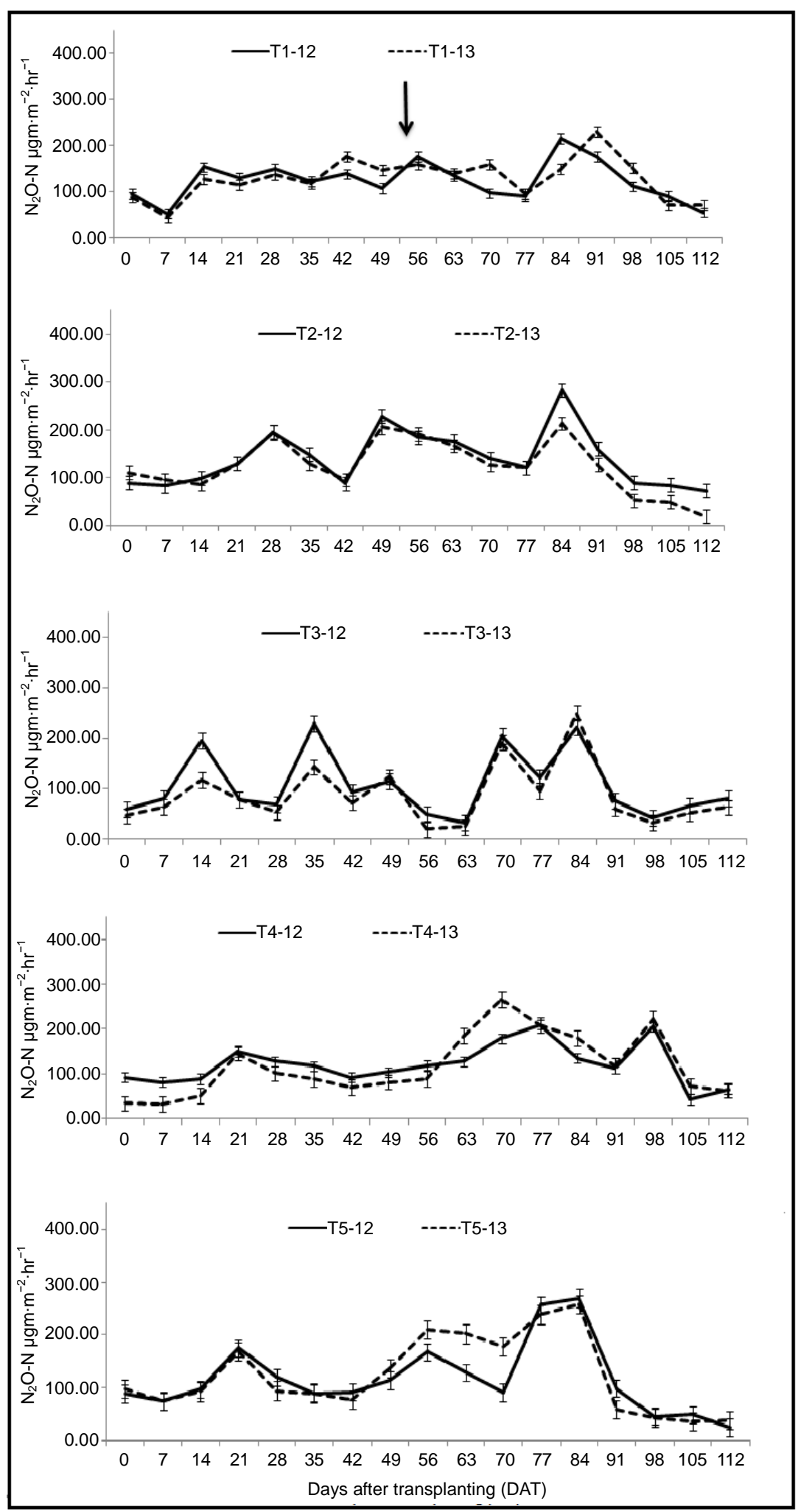

Figure 2. Nitrous oxide flux $\left(\mu \mathrm{gm} \cdot \mathrm{m}^{-2} \cdot \mathrm{h}^{-1}\right)$ recorded from different treatments during the both the years of experimentation. Arrows in T1 indicate time of split application of urea fertilizer. Vertical bars represent standard error. NB: T1: NPK (control), T2: Cow manure, T3: Rice straw, T4: Poultry manure, T5: Sugarcane bagasse. 
Table 3. Variations in $\mathrm{N}_{2} \mathrm{O}-\mathrm{N}$ emission from rice under the effect of different treatments ${ }^{3}$.

\begin{tabular}{|c|c|c|c|c|c|c|c|c|c|c|c|c|c|c|c|c|c|}
\hline \multirow[t]{2}{*}{ Treatment [1] } & \multicolumn{17}{|c|}{ DAYS AFTER TRANSPLANTING (DAT) } \\
\hline & 0 & 7 & 14 & 21 & 28 & 35 & 42 & 49 & 56 & 63 & 70 & 77 & 84 & 91 & 98 & 105 & 112 \\
\hline T1 & 92.36 & 48.95 & 140.99 & 123.02 & 144.02 & 120.25 & 158.01 & 127.38 & 168.02 & 138.02 & 127.96 & 93.17 & 182.25 & 202.58 & 131.89 & 81.51 & 63.36 \\
\hline 11 & A & A & A & A & $\mathrm{AB}$ & A & B & A & A & A & A & A & A & A & B & A & A \\
\hline 12 & A & B & A & A & B & A & $\mathrm{AB}$ & A & B & A & A & $\mathrm{AB}$ & A & A & $\mathrm{AB}$ & A & A \\
\hline T3 & 52.91 & 72.63 & 156.26 & 105.66 & 60.57 & 186.43 & 82.32 & 119.47 & 35.23 & 28.26 & 197.16 & 109.21 & 235.33 & 68.61 & 37.01 & 59.44 & 72.43 \\
\hline 13 & A & $\mathrm{AB}$ & A & A & A & A & A & A & A & A & A & $\mathrm{AB}$ & A & A & A & A & A \\
\hline & 63.96 & 58.10 & 70.72 & 148.83 & 115.4 & 103.87 & 81.73 & 93.88 & 104.38 & 157.77 & 222.96 & 210.8 & 158.59 & 116.3 & 215.57 & 58.65 & 65.05 \\
\hline $\mathrm{T} 4$ & A & $\mathrm{AB}$ & A & A & $\mathrm{AB}$ & A & A & A & $\mathrm{AB}$ & A & A & BC & A & A & C & A & A \\
\hline & 94.27 & 75.37 & 95.62 & 172.68 & 107.89 & 90.18 & 85.44 & 126.47 & 189.59 & 166.45 & 134.91 & 248.91 & 264.65 & 79.29 & 52.9 & 44.8 & 31.46 \\
\hline 15 & A & $\mathrm{AB}$ & A & $\mathrm{A}$ & B & A & A & A & B & A & A & $\mathrm{C}$ & A & A & $\mathrm{AB}$ & A & $\mathrm{A}$ \\
\hline
\end{tabular}

N.B. T1: NPK (control), T2: Cow manure, T3: Rice straw, T4: Poultry manure, T5: Sugarcane bagasse.

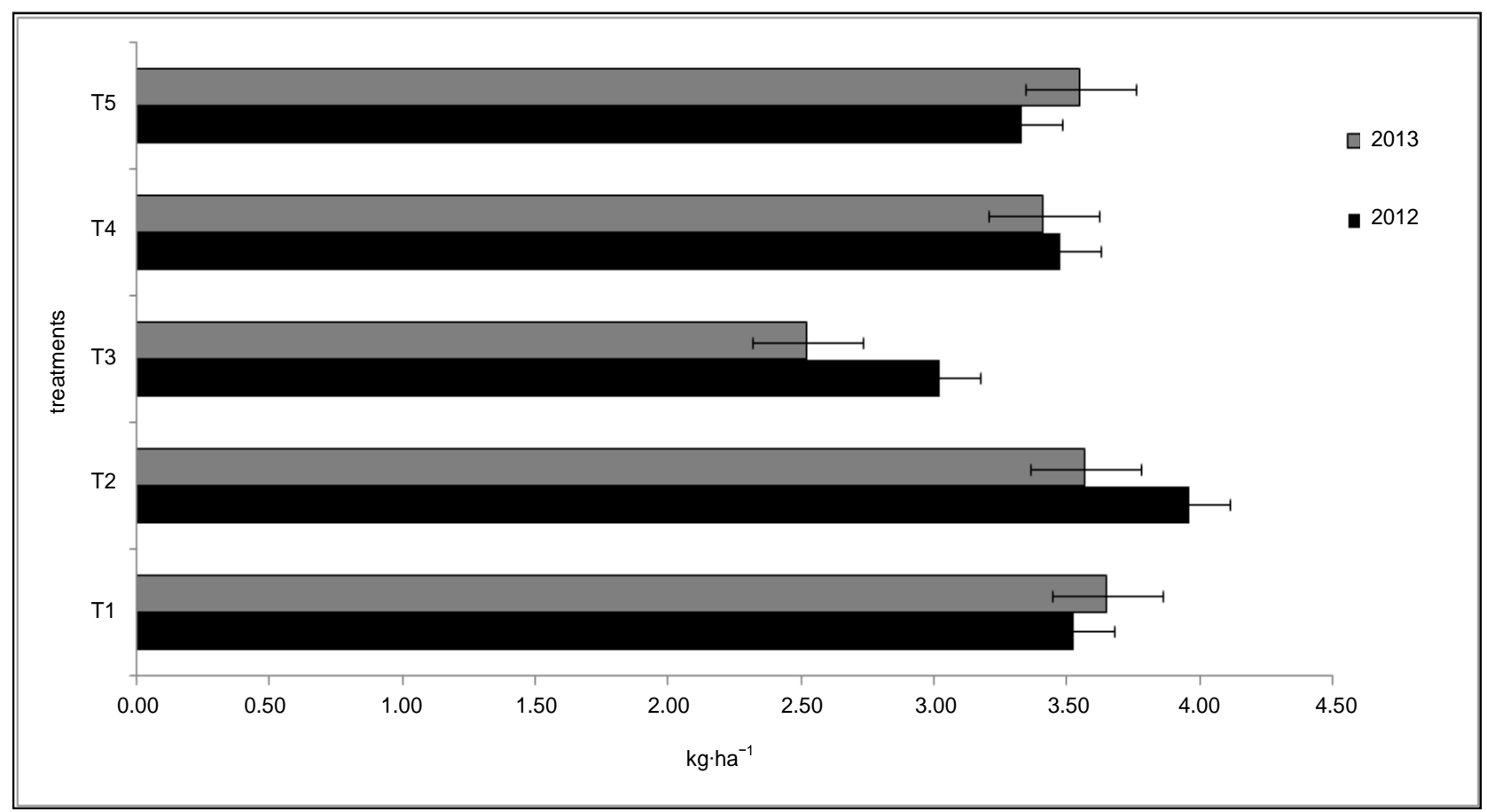

Figure 3. Seasonal cumulative emission $\left(E_{\text {sif }}\right)$ of rice under different treatments during 2012 and 2013. Vertical bars represent standard errors of mean $(n=3)$. NB:T1: NPK (control), T2: Cow manure, T3: Rice straw, T4: Poultry manure, T5: Sugarcane bagasse.

emission [20] [33] and similar mechanism may result in high $\mathrm{N}_{2} \mathrm{O}$ emission recorded during the panicle initiation (56 - 63 DAT) and post anthesis stages (84 - 98 DAT) in the present study. At conventional application of NPK (T1) the emission peaks coincided with split application of nitrogenous fertilizer (urea) doses at tillering (21 DAT) and panicle initiation stages (56 DAT) due to availability of inorganic nitrogen for microbial processes of nitrification and denitrification a mechanism suggested by [20] [30]. Irrespective of the treatments the emission of $\mathrm{N}_{2} \mathrm{O}$ from the treated plots followed a similar trend throughout the cropping season and a decrease in $\mathrm{N}_{2} \mathrm{O}$ emission after maturation of the crop up to harvesting stage was observed.

Organic carbon content of soil is an important regulatory factor for nitrification and denitrification. The nitrifiers and denitrifiers use organic carbon compounds as electron donors for energy and synthesis of cellular

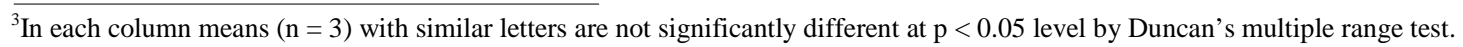


constituents [19] [34] [35]. In the present experiments, high fluxes of $\mathrm{N}_{2} \mathrm{O}-\mathrm{N}$ were observed when there was an increase in the organic carbon in the field. A general understanding is that soils with high levels of organic carbon content has a greater propensity for $\mathrm{N}_{2} \mathrm{O}$ formation than soils with low levels, notably after $\mathrm{N}$ application [36] or residue decomposition [37] which results in stimulation of microbial growth and activity and subsequently increases the consumption of $\mathrm{O}_{2}$ generating anaerobic conditions necessary for denitrification [38] [39] and a similar mechanism might operate resulting in high peaks of $\mathrm{N}_{2} \mathrm{O}$ (coinciding with high organic carbon in the soil) in our study. The Pearson product of correlation exhibited a positive effect of soil organic carbon with nitrous oxide emission. $\mathrm{N}_{2} \mathrm{O}$ emission from soils is strongly influenced by the water content. There is a general concept that rice fields due to its flooded conditions produces less amount of nitrous oxide then well aerated and dry soils. However, in moist soils, the rate of gas diffusion and aeration decreases which reduces $\mathrm{NO}$ to $\mathrm{N}_{2} \mathrm{O}$ which makes $\mathrm{N}_{2}$ the major end product of denitrification and $\mathrm{N}_{2} \mathrm{O}$ the dominant product released to the atmosphere [40]. $\mathrm{N}_{2} \mathrm{O}$ emissions have their optimum in the range of $40 \%-60 \%$ water content in the soil depending upon its type. In our study the soil water content (\%) ranged from $20 \%-78 \%$. Higher emissions were recorded when there was low field water content which may be attributed to increased rate of nitrification as evident from the high soil nitrate - $\mathrm{N}$ content (data not shown). The mineralized nitrogen in soils nitrate $-\mathrm{N}\left(\mathrm{kg}^{-\mathrm{ha}^{-1}}\right)$ and revealed a more strong correlation with $\mathrm{N}_{2} \mathrm{O}-\mathrm{N}$ emission than ammonium $-\mathrm{N}\left(\mathrm{kg} \cdot \mathrm{ha}^{-1}\right)$ irrespective of the treatments. It was observed that when the amount of $\mathrm{NH}_{4}^{+}$content of the soil increased there was a decline in $\mathrm{NO}_{3}^{-} \mathrm{N}$ content and vice versa which resulted in $\mathrm{N}_{2} \mathrm{O}$ being emitted to the atmosphere either by the process of nitrification or denitrification. Our results are in agreement with [41] who reported a similar trend.

\subsection{Effect of Organic Residues on Plant Growth, Rice Productivity and Soil Quality}

Application of organic residues resulted in a considerable variation in plant growth, biomass production and carbon utilization efficiency (CER) of the crops at maturity. Irrespective of the treatments, plant height was initially low up to 14 DAT, there after an increase in plant height in all the treatments were recorded till 84 DAT. Maximum plant height was recorded in T1 (0.85 \pm 0.19 meter) and lowest in T3 ( $0.67 \pm 0.16$ meter) (Figure 4(a)).

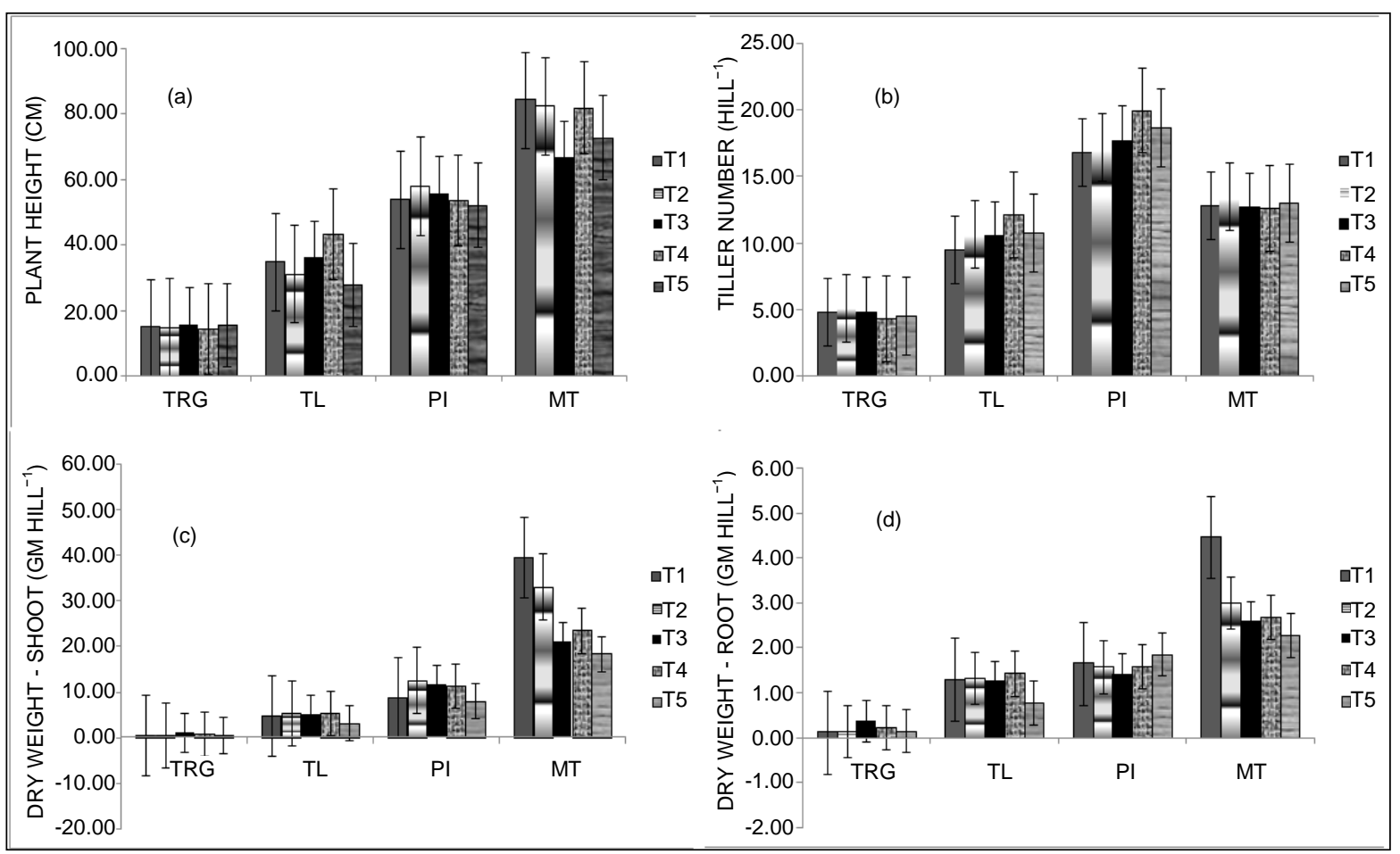

Figure 4. variations of plant growth parameters and above ground and below ground dry mater of rice during active growth and reproductive stages. Vertical Bars represent standard error of mean $(n=4)$. (a) Plant height, (b) Tiller number, (c) Shoot Dry matter and (d) Root dry matter. NB: TRG: transplanting, TL: tillering stage, PI: Panicle initiation stage, MT: maturation stage. 
During the study, observation of the tiller number per hill did not show noticeable difference within the treatments (Figure 4(b)). Shoot dry weight increased up-to panicle maturation stage where it reached a maximum and then gradually decreased towards the end of the season (Figure 4(c)). This was probably due to senescence of the older leaves and non bearing tillers. The root dry weight followed a similar trend with shoot dry weight which increased during the active crop growing season and decreased thereafter up to the end. Panicle initiation stage resulted in maximum dry matter accumulation in roots under T1, T3 and T4 (Figure 4(d)).

Significant variation in yield and yield attributing parameters due to application of different organic residues are presented in Table 4. In our study application of organic residues as substitutes of chemical fertilizer could not significantly affect the yield as compared to the conventional chemical fertilizer (T1, NPK) application as revealed from statistical data analysis. However, higher grain yield was recorded in T3 $\left(2.81 \mathrm{t}^{\mathrm{t}} \mathrm{ha}^{-1}\right)$ followed by T1 (2.69 tha $\left.{ }^{-1}\right)$, T4 (2.66 t ha $\left.{ }^{-1}\right)$, T5 (2.66 tha $\left.{ }^{-1}\right)$ and lowest in T2 (2.54 tha $\left.{ }^{-1}\right)$. Harvest index recorded was also highest in T3 and lowest in T2 without much difference among the treatments. Higher grain yield may be attributed due to higher nutrient availability caused by greater immobilization of soil N compared to T1 (NPK) which may have influenced the crop $\mathrm{C}$ and $\mathrm{N}$ uptake and thus increasing the photosynthesis rate [42] and subsequently photosynthate partitioning towards the panicles and developing grains as explained by Baruah et al. [43]. Yield attributing parameters varied significantly among different treatments as shown in Table 4.

Addition of organic residues in the field significantly affected the total organic carbon (SOC) and total carbon content of the soils. An increase in organic carbon of the experimental field was observed immediately after rice transplanting $(2.3 \%-2.9 \%)$ with a maximum during active vegetative growth $(1.5 \%-2.3 \%)$ followed by a higher organic carbon percentage at reproductive stages (1.3\% - 2.4\%) (Figure 5). Thereafter, a declining trend was observed and the organic carbon content remained fairly constant during the rest of the crop growing season up-to harvesting of the crop. Maximum organic carbon (SOC) content was found at the T5 followed by T3 (p value $=0.000$; $\mathrm{LD}=0.012$ and 0.009 ) which may be the result of higher decomposition and mineralization rate of the organic residues. This may also enhance the microbial and enzyme activities of the organisms responsible for the transformation of labile C. We did not record any significant variation in the total carbon (TC) content of the soil due to the application of organics. During 2012, the plots had considerable quantity of moisture (79\%) till 84 DAT primarily due to rainfall. The soil moisture content slowly decreased thereafter $(30 \%-36 \%)$ to a negligible level at harvest. The soil moisture was high (78\%) up to 56 DAT owing to rainfall during 2013. Soil temperature under the treatments showed a significant variation $(\mathrm{p}<0.001)$ which is possibly due to differential rates of reactions during transformation of organic contents in the soils. Soil $\mathrm{pH}$ did not show a significant difference among the treatments and ranged between 5.2 and 6.2 irrespective of the treatments.

Table 4. Variations in seasonal integrated flux $\left(E_{\text {sif }}\right)$, yield, and yield attributing parameters of rice under different treatments for both years of experimentation ${ }^{4}$.

\begin{tabular}{|c|c|c|c|c|c|c|c|c|}
\hline Treatment & & YIELD (t/Ha) & HI & $\mathrm{FPM}^{-2}$ & $\mathrm{PL}(\mathrm{cm})$ & TGW(gm) & ST (\%) & HDG\% \\
\hline T1 & & $2.79 \mathrm{~A}$ & $41.51 \mathrm{~A}$ & 421.88B & $20.57 \mathrm{~A}$ & $23.85 \mathrm{~A}$ & $30.12 \mathrm{~A}$ & $76.45 \mathrm{C}$ \\
\hline $\mathbf{T 2}$ & & $2.54 \mathrm{~A}$ & $43.47 \mathrm{~A}$ & $344.88 \mathrm{~A}$ & $18.90 \mathrm{~A}$ & $22.68 \mathrm{~A}$ & $42.85 \mathrm{C}$ & $73.43 \mathrm{~B}$ \\
\hline T3 & & $2.73 \mathrm{~A}$ & $44.44 \mathrm{~A}$ & $340.13 \mathrm{~A}$ & $20.57 \mathrm{~A}$ & $22.99 \mathrm{~A}$ & $30.15 \mathrm{~A}$ & $75.67 \mathrm{C}$ \\
\hline T4 & & $2.65 \mathrm{~A}$ & $44.08 \mathrm{~A}$ & $386.88 \mathrm{AB}$ & $20.49 \mathrm{~A}$ & $23.40 \mathrm{~A}$ & $34.18 \mathrm{~B}$ & $70.43 \mathrm{~A}$ \\
\hline T5 & & $2.66 \mathrm{~A}$ & $45.19 \mathrm{~A}$ & 376.63AB & $20.67 \mathrm{~A}$ & $22.68 \mathrm{~A}$ & $28.29 \mathrm{~A}$ & $69.35 \mathrm{~A}$ \\
\hline Stnd error & & 0.68 & 0.512 & 7.56 & 0.271 & 0.23 & 0.326 & 0.324 \\
\hline \multirow[t]{3}{*}{ P-value } & Year & 0.79 & 0.52 & 0.59 & 0.78 & 0.68 & 0.49 & 0.00 \\
\hline & Treatment & 0.85 & 0.574 & 0.01 & 0.22 & 0.43 & 0.00 & 0.00 \\
\hline & Year*treatment & 0.99 & 0.625 & 0.98 & 0.97 & 0.84 & 0.00 & 0.07 \\
\hline
\end{tabular}

NB: HI: harvest index, $\mathrm{FPM}^{-2}$ : fertile panicle meter ${ }^{-2}$, PL: panicle length, TGW: thousand grain weight, ST (\%): sterility, HDG (\%): high density grain.

${ }^{4}$ Values (mean, $\mathrm{n}=4$ ) followed by same letters are not significantly different from each other in the same column at $\mathrm{p}<0.05$. 


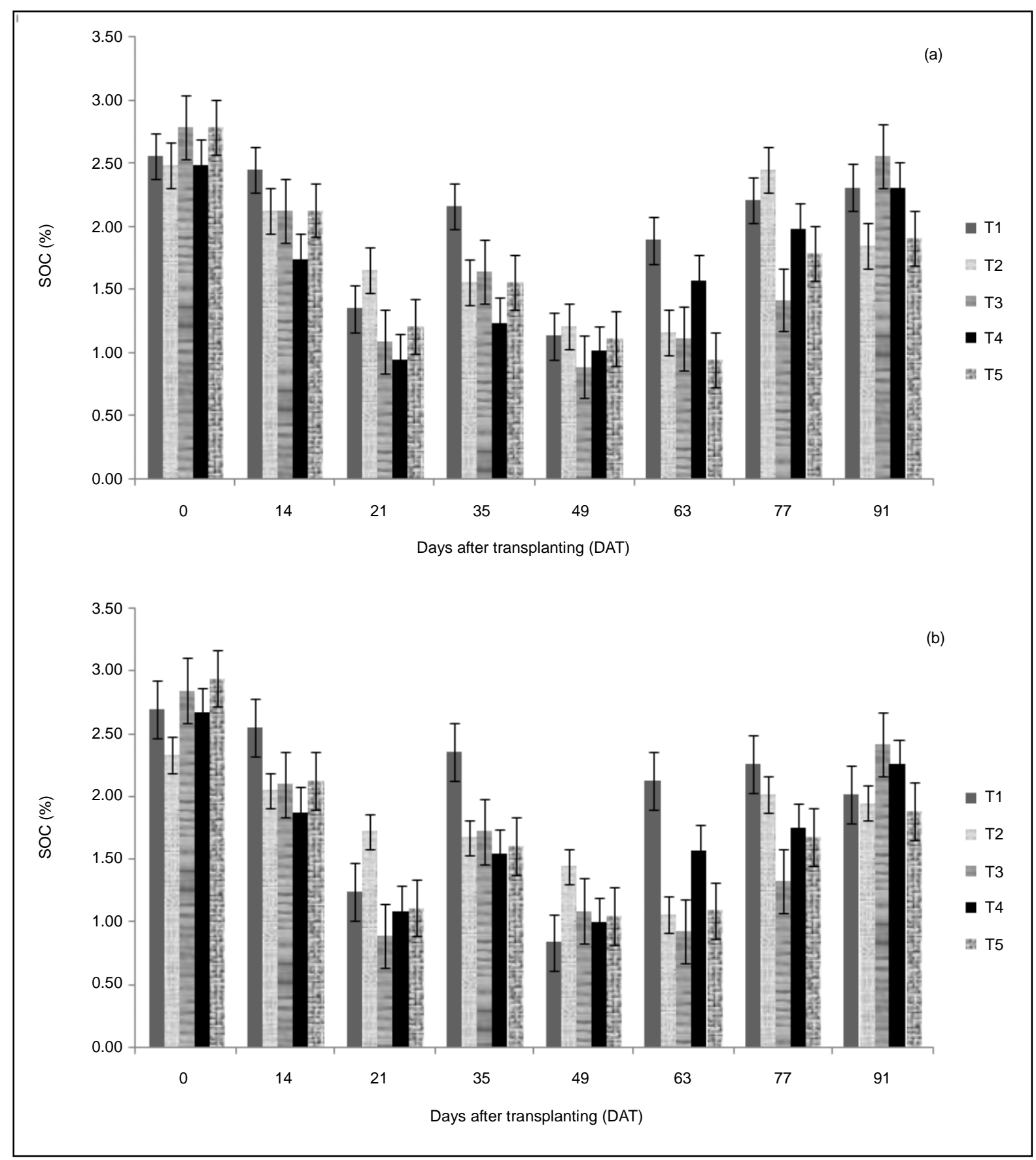

Figure 5. Variations in Soil organic carbon (SOC\%) during the years of experimentation, (a) 2012 and (b) 2013. Vertical bars represent standard error of mean $(n=3)$.

\subsection{Impact and Intensity of Organic Residues on CEE, CER, Plant Growth, Productivity and $\mathrm{N}_{2} \mathrm{O}$ Emission}

Carbon equivalent emission (CEE) and Carbon efficiency ratio (CER) are related to each other, where positive values expressed as $\mathrm{kg} \mathrm{CO}_{2}$ equivalent per grain yield indicates a net source of GHGs to the atmosphere while negative values indicate a net sinks of GHG to the soils [7]. In this study the effects of organic residue amendment on the observed qualities of plant growth, productivity and $\mathrm{N}_{2} \mathrm{O}$ emission followed a more or less proportional trend for both the years. $\mathrm{N}_{2} \mathrm{O}$ emission was found to be higher from plots treated with cow manure (T2) 
resulting in higher CEE (306.47 $\mathrm{kg} \mathrm{CO}_{2} \mathrm{ha}^{-1}$ ) as compared to control (T1). Other treatments, T3, T4 and T5 resulted in lower emissions after two years of study (Table 5). The estimation of CEE showed that reduction in emission compared to control may provide a mitigation option from the rice paddies. Also comparing the CER it is revealed that decreased values of CEE and high value of CER would be beneficial for rice productivity and an effective option for mitigating $\mathrm{N}_{2} \mathrm{O}$ emission from rice ecosystem. This relationship has also been explained by Das and Adhya [30] during their study on combined application of organic manures and inorganic fertilizer on both methane and nitrous oxide emission from rice.

The calculated residue effect intensity (REI, \%) values for plant growth, crop productivity and $\mathrm{N}_{2} \mathrm{O}-\mathrm{N}$ emission are presented in Table 6. The residue amendment exerted a varied effect on plant growth, rice productivity and reducing nitrous oxide emission compared to the corresponding control treatment. A positive effect of crop residue amendment was evidenced on rice productivity and mitigating nitrous oxide emission under the influence of T3 during this study. T4 and T5 also showed decreased values $\mathrm{N}_{2} \mathrm{O}$ emission without any positive effect on grain productivity. Plant growth parameters such as plant height and tiller number also showed a decreased effect due to organic residues as compared to control. Reports of such sustainable effect of organic residues as substitutes of chemical fertilizers in rice fields are not available from this part of the country. However, a study of organic substitution in the fertilizer schedule on wheat crop, where FYM and CR was applied at different ratio in combination with inorganic fertilizer (NPK) and revealed positive effects of organic residues on crop yield and SOC sequestration [44]. But this work did not involve the estimation of any Greenhouse gases (GHGs). Combination of organic manures and crop residues with chemical $\mathrm{N}$ fertilizers are reported where judicious use of the residues and management of the $\mathrm{C}: \mathrm{N}$ ratio mitigates the emission of green house gas from rice fields are been addressed previously [7] [17] [19] [28] [30]. Their findings are supportive to our results of impact of organic residues on GHG emissions and reduction. The estimation REI\% of soil quality was not influenced by the treatments over two years of experimentation.

\section{Conclusion}

Cultivating inherently better soil can lead to lower GHG emissions without sacrificing environmental integrity. For a sustainable agriculture, recycling of organic wastes and crop residues is growing new interests worldwide. Reusing bio-organic materials from agriculture and animal husbandry provides sources of soil organic matter

Table 5. Seasonal amounts and overall magnitude of variation in $\mathrm{N}_{2} \mathrm{O}$ emission and $\mathrm{C}$ intensity emissions under different treatments ${ }^{5}$.

\begin{tabular}{|c|c|c|c|c|c|}
\hline Treatments & $\begin{array}{l}\text { Average } \mathrm{N}_{2} \mathrm{O}-\mathrm{N} \text { flux } \\
\quad\left(\mu \mathrm{gm} \cdot \mathrm{m}^{-2} \cdot \mathrm{h}^{-1}\right)\end{array}$ & $\begin{array}{l}\text { Total } \mathrm{N}_{2} \mathrm{O}-\mathrm{N} \text { emission } \\
\quad\left(\mu \mathrm{gm} \cdot \mathrm{m}^{-2} \cdot \mathrm{h}^{-1}\right)\end{array}$ & $\begin{array}{c}E_{\text {sif }} \\
\left(\mathrm{kg}^{-1} \cdot \mathrm{ha}^{-1}\right)\end{array}$ & $\begin{array}{l}\text { Carbon equivalent emission } \\
(\mathrm{CEE})\left(\mathrm{CO}_{2} \text { eq. } \mathrm{kg} \cdot \mathrm{ha}^{-1}\right)\end{array}$ & $\begin{array}{l}\text { Carbon efficiency } \\
\text { ratio (CER) }\end{array}$ \\
\hline \multicolumn{6}{|c|}{2012} \\
\hline $\mathrm{T} 1$ & 123.78 & 2104.21 & $3.52 \mathrm{D}$ & $286.08 \mathrm{D}$ & $9.37 \mathrm{AB}$ \\
\hline $\mathrm{T} 2$ & 139.96 & 2379.26 & $3.96 \mathrm{E}$ & $321.84 \mathrm{E}$ & $7.92 \mathrm{~A}$ \\
\hline T3 & 106.76 & 1814.85 & $3.02 \mathrm{~A}$ & $245.44 \mathrm{~A}$ & 11.39 B \\
\hline $\mathrm{T} 4$ & 121.65 & 2068.05 & $3.47 \mathrm{C}$ & $282.02 \mathrm{C}$ & $9.42 \mathrm{AB}$ \\
\hline T5 & 117.54 & 1998.15 & 3.33 B & 270.64 B & $9.76 \mathrm{AB}$ \\
\hline \multicolumn{6}{|c|}{2013} \\
\hline $\mathrm{T} 1$ & 128.43 & 2183.30 & $3.65 \mathrm{E}$ & $296.65 \mathrm{E}$ & $9.07 \mathrm{~A}$ \\
\hline $\mathrm{T} 2$ & 124.96 & 2124.32 & $3.57 \mathrm{D}$ & 290.14 D & $8.75 \mathrm{~A}$ \\
\hline T3 & 87.64 & 1489.81 & $2.52 \mathrm{~A}$ & 204.81 A & $13.80 \mathrm{~B}$ \\
\hline $\mathrm{T} 4$ & 119.12 & 2025.06 & $3.41 \mathrm{~B}$ & 277.14 B & $9.61 \mathrm{~A}$ \\
\hline T5 & 124.01 & 2108.10 & $3.55 \mathrm{C}$ & $288.52 \mathrm{C}$ & $9.26 \mathrm{~A}$ \\
\hline
\end{tabular}

${ }^{5}$ In each column means $(n=3)$ with similar letters are not significantly different at $\mathrm{p}<0.05$ level by Duncan’s multiple range test. Statistical analysis for total and average $\mathrm{N}_{2} \mathrm{O}$ flux was not done and not shown. 
Table 6. Changes in residue effect intensity (REI, \%) on $\mathrm{N}_{2} \mathrm{O}$ emission, rice productivity and $\mathrm{C}$ intensity under organic residue amendment.

\begin{tabular}{|c|c|c|c|c|c|c|c|c|c|}
\hline \multirow[b]{2}{*}{ Treatment } & \multicolumn{5}{|c|}{ Productivity and emission } & \multicolumn{4}{|c|}{ Plant growth } \\
\hline & $\begin{array}{l}\text { Seasonal total } \\
\mathrm{N}_{2} \mathrm{O} \text { flux }\end{array}$ & CEE & YIELD & CER & HI & $\mathrm{PH}$ & $\mathrm{TN}$ & BMS & BMR \\
\hline \multicolumn{10}{|c|}{2012} \\
\hline $\mathrm{T} 1$ & - & - & - & - & - & - & - & - & - \\
\hline $\mathrm{T} 2$ & -11.80 & 12.50 & -4.93 & -15.50 & 2.52 & -2.15 & 2.63 & -17.23 & -30.04 \\
\hline T3 & -5.19 & -14.20 & 4.28 & 21.55 & 2.52 & -20.25 & 7.89 & -46.50 & -39.22 \\
\hline $\mathrm{T} 4$ & -8.12 & -1.42 & -0.98 & 0.45 & 3.39 & -0.60 & 7.89 & -40.94 & -38.91 \\
\hline $\mathrm{T} 5$ & -8.61 & -5.40 & -1.50 & 4.12 & 4.65 & -13.97 & 0.00 & -52.34 & -47.94 \\
\hline \multicolumn{10}{|c|}{2013} \\
\hline $\mathrm{T} 1$ & - & - & - & - & - & - & - & - & - \\
\hline $\mathrm{T} 2$ & -5.62 & -2.19 & -5.62 & -3.51 & -3.43 & -2.07 & 7.69 & -15.39 & -34.98 \\
\hline $\mathrm{T} 3$ & 1.25 & -30.96 & 5.00 & 52.08 & -3.43 & -21.52 & -10.26 & -47.86 & -45.09 \\
\hline $\mathrm{T} 4$ & -1.02 & -6.58 & -1.02 & 5.94 & -2.47 & -4.61 & -10.26 & -40.15 & -40.65 \\
\hline T5 & -0.74 & -2.74 & -0.74 & 2.05 & -1.47 & -12.98 & 2.56 & -54.76 & -49.61 \\
\hline
\end{tabular}

NB: CEE: carbon equivalent emission; CER: carbon efficiency ratio; HI: harvest index; PH: plant height; TN: tiller number; BMS: shoot dry weight; BMR: root dry weight.

and plant nutrients. Addition of these residues not only helps in sustaining crop productivity but also helps in reducing the use of chemical nitrogenous fertilizers and conserving Nitrogen in the cropping systems. The experiment undertaken on pre-monsoon rice ecosystem reveals broad fluctuations of $\mathrm{N}_{2} \mathrm{O}$ emission rates under the effect of different organic residues. In our study, application of rice straw results in lower $\mathrm{N}_{2} \mathrm{O}$ emission which may result from higher amount of lignin in rice residues which decreases the degradation of organic $\mathrm{C}$ and subsequently reduces the available $\mathrm{C}$ supply and this depresses the nitrification and denitrification processes. Our results are also in good agreement with Lou et al. [17]. Environmentally sound and economically feasible biological mitigation strategies can be developed to minimize $\mathrm{N}_{2} \mathrm{O}$ emission from agriculture, if proper residue management is selected on the basis of physiological characteristics of rice varieties. In our experiment rice straw (C: $\mathrm{N}=41: 1)$ applied @ $10 \mathrm{t}^{\mathrm{h}} \mathrm{ha}^{-1}$ resulted in reduction of $\mathrm{N}_{2} \mathrm{O}$ flux from the rice field and increased the rice grain productivity. Further research is needed to understand the role of different soil factors on $\mathrm{N}_{2} \mathrm{O}$ emission under the influence of various soil and fertilizer management practices which can help to shape mitigation strategies accordingly and modify existing agricultural and fertilization techniques to curtail the gaseous emissions to a great extent. The study will also open up a new area of exploration for agricultural policy makers for sustainable agriculture and soil environment.

\section{Acknowledgements}

Thanks to Dr. B. P. Baruah, Former Head of the Department, Coal Chemistry Division, CSIR-NEIST, Jorhat, Assam, India for providing necessary instrumental facilities for analysis and Ms. Dipti Gorh, MSc., Environmental Science for her technical help.

\section{References}

[1] Ma, Y.C., Zhang, X.X., Sun, L.Y., Yang, B., Wang, J.Y., Yin, B., Yan, X.Y. and Xiong, Z.Q. (2012) Mitigation of Nitrous Oxide Emissions from Paddy Soil under Conventional and No-Till Practices Using Nitrification Inhibitors during the Winter Wheat-Growing Season. Biology and Fertility of Soils, 49, 627-635. http://dx.doi.org/10.1007/s00374-012-0753-7

[2] McSwiney, C.P. and Robertson, G.P. (2005) Non-Linear Response of $\mathrm{N}_{2} \mathrm{O}$ Flux to Incremental Fertilizer Addition in a 
Continuous Maize (Zea mays L.) Cropping System. Global Change Biology, 11, 1712-1719. http://dx.doi.org/10.1111/j.1365-2486.2005.01040.x

[3] Van Groenigen, J.W., Velthof, G.L., Oenema, O., Van Groenigen, K.J. and Van Kessel, C. (2010) Towards an Agronomic Assessment of $\mathrm{N}_{2} \mathrm{O}$ Emissions: A Case Study for Arable Crops. European Journal Soil Science, 61, 903-913. http://dx.doi.org/10.1111/j.1365-2389.2009.01217.x

[4] Smith, P., Martino, D., Cai, Z., Gwary, D., Janzen, H., Kumar, P., McCarl, B., Ogle, S., O’Mara, F., Rice, C., Scholes, B. and Sirotenko, O. (2007) Agriculture. In: Metz, B., Davidson, O.R., Bosch, P.R. and Dave, R., Eds., Climate Change 2007: Mitigation Contribution of Working Group III to the Fourth Assessment Report of the Intergovernmental Panel on Climate Change, Cambridge University Press, Cambridge, 473-540.

[5] Phillips, R.L., Tanaka, D.L., Archer, D.W. and Hanson, J.D. (2009) Fertilizer Application Timing Influences Greenhouse Gas Fluxes over a Growing Season. Journal of Environmental Quality, 38, 1569-1579. http://dx.doi.org/10.2134/jeq2008.0483

[6] Galloway, J.N., Aber, J.D., Erisman, J.W., Seitzinger, S.P., Howarth, R.W., Cowling, E.B. and Cosby, B.J. (2003) The Nitrogen Cascade. BioScience, 53, 341-356. http://dx.doi.org/10.1641/0006-3568(2003)053[0341:TNC]2.0.CO;2

[7] Bhatia, A., Sasmal, S., Jain, N., Pathak, H., Kumar, R. and Singh, A. (2010) Mitigating Nitrous Oxide Emissions from Soils under Conventional and No Tillage in Wheat Using Nitrification Inhibitors. Agriculture, Ecosystems and Environment, 136, 247-253. http://dx.doi.org/10.1016/j.agee.2010.01.004

[8] De Urzedo, D.I., Franco, M.P., Pitombo, L.M. and Do Carmo, J.B. (2013) Effects of Organic and Inorganic Fertilizers on Greenhouse Gas (GHG) Emissions in Tropical Forestry. Forest Ecology and Management, 310, 37-44. http://dx.doi.org/10.1016/j.foreco.2013.08.018

[9] Scott, A., Ball, B.C., Crichton, I.J. and Aitken, M.N. (2000) Nitrous Oxide and Carbon Dioxide Emissions from Grasslands Amended with Sewage Sludge. Soil Use Management, 16, 35-41. http://dx.doi.org/10.1111/j.1475-2743.2000.tb00170.x

[10] Zou, J., Huang, Y., Jiang, J., Zheng, X., and Sass, R.L. (2005) A 3-Year Field Measurement of Methane and Nitrous Oxide Emissions from Rice Paddies in China: Effects of Water Regime, Crop Residue, and Fertilizer Application. Global Biogeochemical Cycles, 19, Article ID: GB2021. http://dx.doi.org/10.1029/2004GB002401

[11] Pandey, A., Mai, V.T., Vu, D.Q., Bui, T.P.L., Mai, T.L.A., Jensen, L.S. and de Neergaard, A. (2014) Organic Matter and Water Management Strategies to Reduce Methane and Nitrous Oxide Emissions from Rice Paddies in Vietnam. Agriculture, Ecosystems and Environment, 196, 137-146. http://dx.doi.org/10.1016/j.agee.2014.06.010

[12] Ge, G.F., Li, Z.J., Fan, F.L., Chu, G.X., Hou, Z.N. and Liang, Y.C. (2010) Soil Biological Activities and Their Seasonal Variations in Response to Long Term Application of Organic and Inorganic Fertilizers. Plant and Soil, 326, 31-44. http://dx.doi.org/10.1007/s11104-009-0186-8

[13] Uprety, D.C., Dhar, S., Hongmin, D., Kimball, B.A., Garg, A. and Upadhya, J. (2012) Technologies for Climate Change Mitigation-Agriculture Sector. UNEP Riso Centre for Energy, Climate and Sustainable Development, Department of Management and Engineering Technical University of Denmark (DTU).

[14] Majumder, B., Mandal, B., Bandypadhyay, P.K., Gangopadhyay, A., Mani, P.K., Kundu, A.L. and Mazumndar, D. (2008) Organic Amendments Influence on Soil Organic Carbon Pools and Rice-Wheat Productivity. Journal of Soil Science Society of America, 72, 775-785. http://dx.doi.org/10.2136/sssaj2006.0378

[15] Chirinda, N., Carter, M.S., Albert, K.R., Ambus, P., Olsen, J.E., Porter, J.R. and Petersen, S.O. (2010) Emissions of Nitrous Oxide from Arable Organic and Conventional Cropping Systems on Two Soil Types. Agriculture, Ecosystems and Environment, 136, 199-208. http://dx.doi.org/10.1016/j.agee.2009.11.012

[16] Yao, Z.S., Zhou, Z.X., Zheng, X.H., Xie, B.H., Mei, B.L., Wang, R., Bahl, K.B. and Zhu, J.G. (2010) Effects of Organic Matter Incorporation on Nitrous Oxide Emissions from Rice-Wheat Rotation Ecosystems in China. Plant and Soil, 327, 315-330. http://dx.doi.org/10.1007/s11104-009-0056-4

[17] Lou, Y.S., Ren, L.X., Li, Z.P., Zhang, T.L. and Kazuyuki, I. (2007) Effect of Rice Residues on Carbon Dioxide and Nitrous Oxide Emissions from a Paddy Soil of Subtropical China. Water, Air, and Soil Pollution, 178,157-168. http://dx.doi.org/10.1007/s11270-006-9187-x

[18] Meng, L., Ding, W.X. and Cai, Z.C. (2005) Long Term Application of Organic Manure and nitrogen Fertilizer on $\mathrm{N}_{2} \mathrm{O}$ Emissions, Soil Quality and Crop Production in a Sandy Loam Soil. Soil Biology and Biochemistry, 37, 2037-2045. http://dx.doi.org/10.1016/j.soilbio.2005.03.007

[19] Li, X.L., Ma, J., Yao, Y.J., Liang, S.L., Zhang, G.B., Xu, H. and Yagi, K. (2014) Methane and Nitrous Oxide Emissions from Irrigated Lowland Rice Paddies after Wheat Straw Application and Midseason Aeration. Nutrient Cycling of Agroecosystem, 100, 65-76. http://dx.doi.org/10.1007/s10705-014-9627-8

[20] Gogoi, B. and Baruah, K.K. (2012) Nitrous Oxide Emissions from Fields with Different Wheat and Rice Varieties. Pedosphere, 22, 112-121. http://dx.doi.org/10.1016/S1002-0160(11)60197-5 
[21] Wang, J.Y., Jia, J.X., Xiong, Z.Q., Khalil, M.A.K. and Xing, G.X. (2011) Water regime-Nitrogen Fertilizer-Straw Incorporation Interaction: Field Study on Nitrous Oxide Emissions from a Rice Agro-Ecosystem in Nanjing, China. Agriculture, Ecosystems and Environment, 141, 437-446.

[22] Ma J., Ma, E.D., Xu, H., Yagi, K., and Cai, Z.C. (2009) Wheat Straw Management Affects $\mathrm{CH}_{4}$ and $\mathrm{N}_{2} \mathrm{O}$ Emissions from Rice Fields. Soil Biology and Biochemistry, 41, 1022-1028. http://dx.doi.org/10.1016/j.soilbio.2009.01.024

[23] Page, A.L., Miller, R.H. and Keeney, D.R. (1982) Methods of Soil Analysis, Part 2. Soil Science Society America, Madison.

[24] Ghosh, S., Wilson, B., Ghoshal, S., Senapati, B. and Mandale, B. (2012) Organic Amendments Influence Soil Quality and Carbon Sequestration in the Indo-Gangetic Plains of India. Agriculture, Ecosystems and Environment, 156, 134141. http://dx.doi.org/10.1016/j.agee.2012.05.009

[25] Awale, R., Chatterjee, A. and Franzen, D. (2013) Tillage and N-Fertilizer Influences on Selected Organic Carbon Fractions in a North Dakota Silty Clay Soil. Soil and Tillage Research, 134, 213-222. http://dx.doi.org/10.1016/j.still.2013.08.006

[26] Yasin, B.A., Ram, M., Singh, S. and Wani, B.A. (2011) Genetic Improvement in Yield, Yield Attributes and Leaf Rust Resistance in Semi-dwarf Wheat Varieties Developed in India from Last 40 Years. International Journal of Agricultural Research, 6, 747-753. http://dx.doi.org/10.3923/ijar.2011.747.753

[27] Intergovernmental Panel on Climate Change (IPCC) (2007) Causes of Change. In: Pachauri, R.K., Reisinger, A. (Eds.), Climate Change 2007, Synthesis Report, Intergovernmental Panel on Climate Change, Geneva, 35-42.

[28] Zhang, A.F., Bian, R.J., Pan, G.X., Cui, L.Q., Hussain, Q., Li, L.Q., Zheng, J.W., Zheng, J.F., Zhang, X.H., Han, X.J. and Yu, X.Y. (2012) Effects of Biochar Amendment on Soil Quality, Crop Yield and Greenhouse Gas Emission in a Chinese Rice Paddy: A Field Study of 2 Consecutive Rice Growing Cycles. Field Crop Research, 127, 153-160. http://dx.doi.org/10.1016/j.fcr.2011.11.020

[29] Bouwman, A.F. (1990) Exchange of Greenhouse Gases between Terrestrial Ecosystems and the Atmosphere. In: Bouwman, A.F., Ed., Soils and the Greenhouse Effect, John Wiley, New York, 61-127.

[30] Das, S. and Adhya, T.K. (2014) Effect of Combine Application of Organic Manure and Inorganic Fertilizer on Methane and Nitrous Oxide Emissions from a Tropical Flooded Soil Planted to Rice. Geoderma, 213, 185-192. http://dx.doi.org/10.1016/j.geoderma.2013.08.011

[31] Mosier, A.R., Duxbury, J.M., Freney, J.R., Heinemeyer, O. and Minami, K. (1996) Nitrous Oxide Emissions from Agricultural Fields: Assessment, Measurement and Mitigation. Plant and Soil, 181, 95-108. http://dx.doi.org/10.1007/BF00011296

[32] von Arnold, K.M., von Nilsson. M., Hanell, B., Weslien, P. and Klemedtsson, L. (2005) Fluxes of $\mathrm{CO}_{2}, \mathrm{CH}_{4}$ and $\mathrm{N}_{2} \mathrm{O}$ from Drained Organic Soils in Deciduous Forests. Soil Biology and Biochemistry, 37, 1059-1071. http://dx.doi.org/10.1016/j.soilbio.2004.11.004

[33] Yang, L.F. and Cai, Z.C. (2005) The Effect of Growing Soybean (Glycine max. L.) on N2O Emission from Soil. Soil Biology and Biochemistry, 37, 1205-1209. http://dx.doi.org/10.1016/j.soilbio.2004.08.027

[34] Tiedje, J.M., Sexstone, A.J., Myrold, D.D. and Robinson, J.A. (1982) Denitrification: Ecological Niches, Competition and Survival. Journal of Microbiology and Serology, 48, 569-583.

[35] Pathak, H. (1999) Emission of Nitrous Oxide from Soils. Current Science, 77, 359-369.

[36] Granli, T. and Bockman, O.C. (1994) Nitrogen Oxide from Agriculture. Norwegian Journal of Agriculture Science, 12, 7-127.

[37] Ciampitti, I.A., Ciarlo, E. A. and Conti, M. E. (2008) Nitrous Oxide Emissions from Soil during Soybean (Glycine max (L.) Merrill) Crop Phenological Stages and Stubbles Decomposition Period. Biology and Fertility of Soils, 44, 581-588. http://dx.doi.org/10.1007/s00374-007-0241-7

[38] Cameron, K.C., Di, H.J. and Moir, J.L. (2013) Nitrogen Losses from the Soil/Plant System: A Review. Annals of Applied Biology, 62, 145-173. http://dx.doi.org/10.1111/aab.12014

[39] Signor, D. and Cerri, C.E.P. (2013) Nitrous Oxide Emissions from Agricultural Soils: A Review. Pesquisa Agropecuária Tropical, 43, 322-338

[40] Davidson, E.A., Keller, M., Erickson, H.E., Verchot, L.V. and Veldkamp, E. (2000) Testing a Conceptual Model of Soil Emissions of Nitrous and Nitric Oxides. Bioscience, 50, 667-680. http://dx.doi.org/10.1641/0006-3568(2000)050[0667:TACMOS]2.0.CO;2

[41] Akiyama, H., Tsuruta, H. and Watanabe, T. (2000) $\mathrm{N}_{2} \mathrm{O}$ and NO Emissions from Soils after the Application of Different Chemical Fertilizers. Chemosphere Global Change Science, 2, 313-320. http://dx.doi.org/10.1016/S1465-9972(00)00010-6

[42] Makino, A. (2011) Photosynthesis, Grain Yield, and Nitrogen Utilization in Rice and Wheat. Plant Physiology, 155, 
125-129. http://dx.doi.org/10.1104/pp.110.165076

[43] Baruah, K.K., Gogoi, B., Borah, L., Gogoi, M. and Boruah, R. (2012) Plant Morpho-Physiological and Anatomical factors Associated with Nitrous Oxide flux from Wheat (Triticum aestivum). Journal of Plant Research, 125, 507-516. http://dx.doi.org/10.1007/s10265-011-0464-4

[44] Saikia, P., Bhattacharya, S.S. and Baruah, K.K. (2015) Organic Substitution in Fertilizer Schedule: Impacts on Soil Health, Photosynthetic Efficiency, Yield and Assimilation in Wheat Grown in Alluvial Soil. Agriculture, Ecosystems and Environment, 203, 102-109. http://dx.doi.org/10.1016/j.agee.2015.02.003 